\title{
Effect of Fertilization with Sludge-Ash Granulates on the Activity of Selected Soil Enzymes
}

\author{
Ewa Możdżer ${ }^{1}$ \\ 1 Department of Environmental Management, West Pomeranian University of Technology, ul. Słowackiego 17, \\ 71-434 Szczecin, Poland \\ e-mail: emozdzer@zut.edu.pl
}

\begin{abstract}
In the two-factorial vegetation experiment, the activity of dehydrogenase, phosphatase and urease was examined under the influence of the applied sludge-ash granulates produced from waste (sewage sludge, ash, sawdust). The research scheme included a control object, four types of fertilizer granulates, three doses and four dates of enzymatic activity indicators determination. The experiment was established in four replications. The size of granulate doses was determined on the basis of their nitrogen content. Dose I, II and III were: $0.24 \mathrm{~g}, 0.48 \mathrm{~g}$ and $0.72 \mathrm{~g}$ $\mathrm{N} \cdot$ pot, respectively. The test plant was rapeseed of Larissa cultivar. The sludge-ash granulates were applied to the pots filled with the soil, in accordance with the experimental scheme. The soil samples for chemical analyses were taken from the top layer $(0-20 \mathrm{~cm})$ of spring rape cultivation four times: May 16, June 2, July 2 - dates from I to III, respectively, and August 2 after harvest - date IV. In average soil samples, the enzymatic activity of dehydrogenase, urease and phosphatase was determined. The research revealed that the highest increase in enzymatic dehydrogenase activity was obtained after applying granulate B, while phosphatases and urease after the application of granulate D. The smallest increase in dehydrogenase and phosphatase activity was obtained after the application of granulate $\mathrm{C}$. The dose size of the applied granulates and date of uptake had a significant impact on the growth activity of the enzymes studied. The activity of dehydrogenase, phosphatases and urease, depending on the type of applied granulate, dose and date of soil sampling, was on average $7.28 \%, 30.5 \%$ and $7.94 \%$ higher, respectively, compared to the control. The correlation coefficient between dehydrogenase activity and urease and phosphatase was positively associated and amounted to $r=0.569$ and $r=0.553$, respectively. The applied fertilization with sludge-ash granulates A, B, C and D stimulated the increase in dehydrogenase, urease, and phosphatase activities in all fertilizer objects.
\end{abstract}

Keywords: soil, granulates sludge-ash, enzymatic activity phosphatase, urease, dehydrogenase.

\section{INTRODUCTION}

The applicable legislation related to environmental protection imposes an obligation on producers or importers to develop or dispose of the generated waste. Waste disposal is associated with financial costs. Therefore, producers of sewage sludge, knowing their fertilizing properties (they contain organic substances and some nutrients for plants), provide them for secondary use in order to fertilize the soils [Antonkiewicz 2010]. In addition, sewage sludge applied to light soils in optimal doses contributes to increasing its enzymatic activity [Antonkiewicz et al., 2018, He et al. 2009, Krzywy et al. 2012, Kulikowski et al. 2019]. Ashes from the coal combustion constitute another waste produced in significant quantities that is stored and managed in various ways. According to Labętowicz et al. [2019] they have positive effect on soil properties, among others: they increase the content of some macroelements and micronutrients, as well as $\mathrm{CaO}$ and $\mathrm{MgO}$, moisture content, and contribute to de-acidification. Bielińska et al. [2009] indicate attention should be paid to the low permeability of coal ash and their negative impact on the activity of some enzymes in soils. Despite these drawbacks, 
results of many studies indicate that ashes used in optimal doses give better results than typical calcium fertilizers [Antonkiewicz 2009]. They are also an abundant source of some nutrients for plants, and create optimal conditions for the development of many soil microorganisms, which has a positive influence. Therefore, attention was paid to the possibility of using the sewage sludge, ashes and sawdust for the production of sludge-ash granulates, which may lead to the increased fertility of soils and soil enzymes activity [Możdżer et al. 2020, Łabętowicz et al. 2019].

Level of enzymatic activity is a fairly sensitive indicator of the soil fertility assessment [Lemanowicz and Koper 2012]. The activity of soil enzymes depends on the optimal humidity, the access of air to soils, type of soil, concentration of heavy metals, $\mathrm{pH}$ values, nitrogen and carbon content, cultivated plant species and its development stages [Bielińska et al. 2013, Trasar-Cepeda et al., 2008, Renella et al. 2007, Wyszkowska et al. 2009, Telesiński et al. 2012]. It is an indicator of ecological changes occurring in the soil environment. Changes in the soil environment depend to a greater extent on the activity of individual enzymes calculated per unit of organic carbon than the activity expressed in substrate units per unit soil mass. Organic fertilization is of great importance, because it determines the carbon content in the soil and, in the majority of cases, it is positively correlated with the activity of enzymes [Kalembasa et al. 2014].

The research aimed to determine the impact of four sludge-ash granulates applied in three doses and collected in four dates, on the activity of soil enzymes: dehydrogenase, phosphatases and urease, during the cultivation of spring rape of Larissa $\mathrm{c} v$.

\section{MATERIAL AND METHODS}

The sludge-ash granulates used for the research were produced from industrial sewage sludge in sewage treatment plants Zakłady Chemiczne Police Grupa Azoty in Police, ash from brown coal combustion in Adamów S.A. power plant, and sawdust from deciduous and coniferous trees. On the basis of the chemical properties of sewage sludge, ash from lignite and sawdust, material compositions of four sludge-ash granulates were developed. Table 1 shows the chemical composition of the produced ash-sediment granulates.

In order to obtain the optimal N:P:K ratio, ammonium phosphate and potassium salt were added to the granulates. The vegetative-pot experiment with the participation of produced granulates was carried out in the Vegetation Hall belonging to ZUT in Szczecin. The soil from the Ap level of the production field of the Agricultural Experimental Station in Lipnik near Stargard was used for the research. This soil is classified as incomplete brown with granulometric composition of strong loamy sand with a content of $12 \%$ of the alluvial parts. In terms of agricultural suitability, the soil belongs to the good rye complex of bonitation class IVb. It was characterized by slightly acidic $\mathrm{pH}$, narrow $\mathrm{C}: \mathrm{N}$ ratio and low organic carbon content. The content of bioavailable forms for phosphorus, potassium and magnesium plants was medium (Table 2).

The research scheme included control object, four types of sludge-ash granulates, three doses and four dates of enzyme activity indicators determination. The experiment was established in four replications. Dose I, II and III amounted to: $0.24 \mathrm{~g} \mathrm{~N} \cdot \operatorname{pot}\left(80 \mathrm{~kg} \mathrm{~N} \cdot \mathrm{ha}^{-1}\right), 0.48 \mathrm{~g} \mathrm{~N} \cdot \operatorname{pot}(160$ $\left.\mathrm{kg} \mathrm{N} \cdot \mathrm{ha}^{-1}\right)$ and $0.72 \mathrm{~g} \mathrm{~N} \cdot \operatorname{pot}\left(240 \mathrm{~kg} \mathrm{~N} \cdot \mathrm{ha}^{-1}\right)$, respectively. The test plant was rapeseed of Larissa cultivar. The size of granulate doses was determined on the basis of their nitrogen content. In addition to granulates, nitrogen supplementation was applied in the form of an aqueous urea solution.

Table 1. Material composition of fertilizer blends expressed in \% dry matter. Orgin: Możdżer and Jałoszyński [2019], Możdżer et al. [2020]

\begin{tabular}{|c|c|c|c|c|c|}
\hline \multirow[t]{2}{*}{ Type of granulate } & $\begin{array}{c}\text { Industrial sewage } \\
\text { sludge }\end{array}$ & Brown coal ash & Sawdust & $\begin{array}{l}\text { Ammonia } \\
\text { phosphate }\end{array}$ & Potassium salt \\
\hline & \multicolumn{5}{|c|}{$\ln \%$} \\
\hline A & 30 & 30 & 10 & 15 & 15 \\
\hline$B$ & 40 & 20 & 10 & 15 & 15 \\
\hline C & 20 & 40 & 10 & 15 & 15 \\
\hline D & 50 & 20 & 10 & 10 & 10 \\
\hline
\end{tabular}


Table 2. The content of the macroelements in the soil used in the experiment. Orgin: Możdżer and Jałoszyński [2019], Możdżer et al. [2020].

\begin{tabular}{|c|c|c|c|c|c|c|c|c|c|c|c|}
\hline \multirow{3}{*}{$\mathrm{pH}_{\mathrm{KCl}}$} & \multicolumn{7}{|c|}{ Total content } & \multirow{3}{*}{$\mathrm{C}: \mathrm{N}$} & \multirow{2}{*}{\multicolumn{3}{|c|}{$\begin{array}{c}\text { Content of assimilable forms } \\
\text { In } \mathrm{mg} \cdot \mathrm{kg}^{-1} \mathrm{~d} . \mathrm{m} .\end{array}$}} \\
\hline & \multicolumn{7}{|c|}{ Total content in $\mathrm{g} \cdot \mathrm{kg}^{-1} \mathrm{~d} . \mathrm{m}$. } & & & & \\
\hline & $\mathrm{C}_{\text {org, }}$ & $\mathrm{N}$ & $P$ & $\mathrm{~K}$ & $\mathrm{Ca}$ & $\mathrm{Mg}$ & $\mathrm{S}$ & & $P$ & K & $\mathrm{Mg}$ \\
\hline 6.0 & 9.63 & 0.86 & 1.50 & 2.57 & 2.11 & 0.56 & 1.25 & 11.2 & 60.9 & 121 & 42.5 \\
\hline
\end{tabular}

Rape was fertilized five weeks after emergence. The dose amount corresponded to $0.276 \mathrm{~g} \mathrm{~N} \cdot$ pot $^{-1}$. The sludge-ash granulates were applied to the pots filled with soil in accordance with the experimental pattern. Then, 20 rape seeds were sown. After reaching $10 \mathrm{~cm}$ test plant height, selection was made, leaving 5 rapeseed plants in each pots.

In order to investigate the impact of individual sludge-ash granulates on soil enzymatic activity, samples were collected at specific intervals during the development of spring rape. They were taken from the top layer $(0-20 \mathrm{~cm})$ of rapeseed plantation four times: May 16, June 2, July 2 - dates marked from I to III, respectively, and August 2 after harvesting the test plant - date IV. Dehydrogenase activity was determined colorimetrically on a Lambda 150 spectrophotometer at a wavelength of $485 \mathrm{~mm}$ after 24-hour incubation at $30^{\circ} \mathrm{C}$ with a TTC solution, according to Thalmana [1969]. Urease activity was determined according to the method based on spectrophotometric measurement of released ammonia after a 2-hour incubation of the soil sample with urea at the concentration of $2.5 \%$ as a substrate at $37^{\circ} \mathrm{C}-\mathrm{Zan}$ tua and Bremnera [1975]; phosphatase according to the Tabatabai [1994] method, organic carbon (ISO 14235), total nitrogen (ISO 13878), $\mathrm{pH}$ - potentiometrically in $1 \mathrm{~mol} \mathrm{KCl}$ solution. The statistical analysis of results was performed using the Statistica 13 software, and differences between the average values were assessed by the Tukey test at the significance of $p=0.05$. The material composition of granules and the chemical properties of the soil were published before the experiment was set up in Możdżer and Jałoszyński [2019], Możdżer et al. [2020].

\section{RESULTS AND DISCUSSION}

The changes of enzymatic processes occurring in the soil during the growing season of plants are characteristic, because they depend on the prevailing atmospheric conditions. It should be noted that enzymes are more active at the end of spring as well as the beginning of summer and autumn [Yang et al., 2008, Krzywy-Gawońska 2012, Kalembasa et al. 2014].

Dehydrogenase, phosphatase and urease activity on various dates of soil sampling are summarized in Tables 3 and 4. The applied sludge-ash granulates $\mathrm{A}, \mathrm{B}, \mathrm{C}$ and $\mathrm{D}$ and increasing doses significantly influenced the increase of activity of tested enzymes. The activity of soil dehydrogenase under the influence of applied sludge-ash granulates A, B, C and D ranged from 9.15 to 10.2 $\mathrm{cm} \cdot \mathrm{H}_{2} \cdot \mathrm{kg}^{-1} \cdot \mathrm{d}^{-1}$. The soil collected from rape plantation on date IV showed greater dehydrogenase activity compared to date I. Dehydrogenase activity higher by $2.0 \%$ was exhibited by the soil on the objects with applied granulate B (40\% sewage sludge, $40 \%$ ash, $10 \%$ sawdust and 15\% ammonium phosphate and $\mathrm{KCl}$ ) in comparison with its activity obtained under the influence of applied granulate C (20\% sewage sludge, $40 \%$ ash, 10\% sawdust and $15 \%$ ammonium phosphate and $\mathrm{KCl}$ ). It can be concluded that higher proportion of sewage sludge and smaller of ash (granulate B) affected the growth of tested enzyme. When analyzing the date of soil sampling, the highest dehydrogenase activity was observed in date IV (August) compared to the first term (May) under the influence of all applied granulates. The soil dehydrogenase activity under the influence of $\mathrm{A}$, B, C and D granulates introduced between harvest dates I and IV (May, August) increased by $3.51 \%, 4.02 \%, 2.57 \%$ and $2.76 \%$, respectively. The highest dehydrogenase activity was recorded under the influence of the applied granulates $\mathrm{A}$ and $\mathrm{C}$, between the applied dose 1 and 3, by $6.31 \%$ and $7.64 \%$, respectively, and the lowest by $3.05 \%$ under the influence of granulate D $(50 \%$ sewage sludge, $20 \%$ ash, $10 \%$ sawdust, ammonium phosphate and $\mathrm{KCl}$ ). The phosphatase activity in the soil under the influence of applied sludgeash granulates A, B, C and D ranged from 15.62 to $16.98 \mathrm{mmol} \mathrm{PNP} \cdot \mathrm{kg}^{-1} \cdot \mathrm{h}^{-1}$ (Table 3).

Single and triple dose of granulate D used, doubled granulate $\mathrm{A}$ and tripled granulate $\mathrm{C}$ caused the highest increase in phosphatase 
Table 3. The impact of sludge-ash granulates on the activity of dehydrogenase $\left(\mathrm{cm}^{3} \cdot \mathrm{H}_{2} \cdot \mathrm{kg}^{-1} \cdot \mathrm{d}^{-1}\right)$ and phosphatase $\left(\mathrm{mmol} \mathrm{PNP} \cdot \mathrm{kg}^{-1} \cdot \mathrm{h}^{-1}\right)$ in the soil

\begin{tabular}{|c|c|c|c|c|c|c|c|c|c|c|c|c|c|c|c|c|c|c|c|}
\hline \multirow{4}{*}{$\begin{array}{c}\text { Type } \\
\text { granulates* }\end{array}$} & \multicolumn{19}{|c|}{ Dose $* \star$} \\
\hline & \multicolumn{5}{|c|}{1} & \multicolumn{5}{|c|}{2} & \multicolumn{5}{|c|}{3} & \multicolumn{4}{|c|}{ Mean } \\
\hline & \multicolumn{19}{|c|}{ Sampling times } \\
\hline & 1 & II & III & IV & mean & 1 & II & III & IV & mean & 1 & II & III & IV & mean & I & II & III & IV \\
\hline \multicolumn{20}{|c|}{ Dehydrogenase in $\mathrm{cm}^{3} \cdot \mathrm{H}_{2} \cdot \mathrm{kg}^{-1} \cdot \mathrm{d}^{-1}$} \\
\hline A & 9.15 & 9.25 & 9.48 & 9.55 & 9.35 & 9.30 & 9.41 & 9.52 & 9.59 & 9.45 & 9.80 & 9.89 & 9.96 & 10.1 & 9.94 & 9.41 & 9.51 & 9.70 & 9.74 \\
\hline$B$ & 9.31 & 9.42 & 9.49 & 9.62 & 9.46 & 9.38 & 9.48 & 9.63 & 9.71 & 9.55 & 9.71 & 9.82 & 9.93 & 10.2 & 9.91 & 9.46 & 9.57 & 9.75 & 9.84 \\
\hline C & 9.05 & 9.10 & 9.21 & 9.27 & 9.16 & 9.24 & 9.29 & 9.38 & 9.47 & 9.35 & 9.73 & 9.82 & 9.90 & 10.0 & 9.86 & 9.34 & 9.40 & 9.54 & 9.58 \\
\hline $\mathrm{D}$ & 9.37 & 9.42 & 9.55 & 9.69 & 9.51 & 9.18 & 9.25 & 9.31 & 9.36 & 9.27 & \begin{tabular}{|l|}
9.68 \\
\end{tabular} & 9.74 & 9.81 & 9.98 & 9.80 & 9.41 & 9.47 & 9.62 & 9.67 \\
\hline Mean & 9.22 & 9.29 & 9.43 & 9.53 & 9.37 & 9.27 & 9.36 & 9.46 & 9.53 & 9.41 & 9.73 & 9.81 & \begin{tabular}{|l|}
9.90 \\
\end{tabular} & 10.1 & 9.88 & 9.40 & 9.48 & 9.65 & 9.72 \\
\hline Control & \multicolumn{19}{|c|}{8.90} \\
\hline \multicolumn{20}{|c|}{$\mathrm{LSD}_{0.05}$ for: type granulates -0.047 , dose -0.037 , interaction -0.081 . } \\
\hline \multicolumn{20}{|c|}{ Phosphatase in mmol PNP $\cdot \mathrm{kg}^{-1} \cdot \mathrm{h}^{-1}$} \\
\hline A & 15.80 & 15.92 & 15.96 & 16.12 & 15.9 & 16.03 & 16.11 & 16.21 & 16.32 & 16.2 & 16.38 & 16.49 & 16.58 & 16.62 & 16.5 & 16.07 & 16.17 & 16.34 & 16.35 \\
\hline B & 15.91 & 16.05 & 16.12 & 16.21 & 16.1 & 15.97 & 16.03 & 16.12 & 16.22 & 16.1 & 16.31 & 16.41 & 16.52 & 16.58 & 16.4 & 16.06 & 16.16 & 16.31 & 16.33 \\
\hline C & 15.62 & 15.67 & 15.71 & 15.82 & 15.7 & 15.82 & 15.91 & 15.98 & 16.06 & 15.9 & 16.47 & 16.54 & 16.63 & \begin{tabular}{|l|}
16.79 \\
\end{tabular} & 16.6 & 15.97 & 16.04 & 16.17 & 16.22 \\
\hline$D$ & 16.71 & 16.78 & 16.89 & 16.98 & 16.8 & 15.93 & 15.98 & 16.06 & \begin{tabular}{|l|}
16.19 \\
\end{tabular} & 16.0 & 16.54 & 16.36 & 16.71 & 16.89 & 16.6 & 16.39 & 16.37 & 16.62 & 16.68 \\
\hline Mean & 16.01 & 16.1 & 16.2 & 16.3 & 16.1 & 15.9 & 16.0 & 16.1 & 16.2 & 16.0 & 16.4 & 16.5 & 16.6 & 16.7 & 16.5 & 16.10 & 16.2 & 16.36 & 16.40 \\
\hline Control & \multicolumn{19}{|c|}{15.1} \\
\hline
\end{tabular}

* Explanations of the material composition of sludge-ash granulates are given as in Table 1.

** The size of granulated doses and the dates of soil samples collection are given "Material and method".

activity compared to other fertilizer objects. The type of applied granulates A, B and C had a significant effect on the increase in phosphatase activity between 1 and 3 doses, by $3.77 \%, 1.86 \%$ and $5.73 \%$, respectively. On the other hand, the introduced doubled dose of granulate D caused a decrease in the activity of phosphatases compared to the single dose by $5.0 \%$. When analyzing the date of soil samples collection, the highest phosphatase activity was found in date IV compared to dates I, II, and III. The increase in phosphatase activity in the soil under the influence of granulates A, B, C and D introduced between dates of sampling 1 and 4 was small and amounted to $1.74 \%$, $1.68 \%, 1.56 \%$ and $1.76 \%$, respectively. Bielińska and Mocek-Płóciniak [2009] indicate that lower phosphatase activity may be caused by the introduction of calcium, which was confirmed in our own research in the case of the applied C. Urease activity ranged from 7.29 to $9.12 \mathrm{mg} \mathrm{N}-\mathrm{NH}_{4} \cdot \mathrm{kg}^{-}$ ${ }^{1} \cdot \mathrm{ha}^{-1}$. The applied single and triple dose of granulate B and doubled granulate D caused the greatest increase in the activity of the tested enzyme in comparison to other fertilizer objects (Table 4).

When analyzing the date of soil sampling, it was found that under the influence of A, B, C and $\mathrm{D}$ granulates, the urease activity in soil between the I and IV harvest (May, August) increased by $2.89 \%, 2.23 \%, 3.73 \%$ and $4.33 \%$, respectively. The soil collected in date IV, under the influence of applied granulates, showed the highest urease activity in comparison with date I and the control. The obtained results of the research are most likely related to the air temperature, which in the examined period (August) was optimal for the development of enzymes and fluctuated from 19.4 to $19.1^{\circ} \mathrm{C}$. The highest urease activity in the soil was recorded under the influence of granulates $\mathrm{C}$ and D between doses 1 and 2 by $19.0 \%$ and $20.0 \%$, respectively, and the decrease in activity between doses 2 and 3 by $6.13 \%$ and $6.44 \%$, respectively. It was found that the type of applied granulates $\mathrm{A}, \mathrm{B}, \mathrm{C}$ and $\mathrm{D}$ had the significant effect on the increase in urease activity between 1 and 3 doses by $7.98 \%, 8.16 \%, 12.1 \%$ and $12.8 \%$, respectively. It could have been caused by a greater uptake of free nitrogen from the air by rape, which was confirmed by the tests carried out. It should be remembered that urease activity can be inhibited by the use of nitrogen fertilizers in ammonium form [Piotrowska and Koper 2007].

The activity of dehydrogenase, phosphatases and urease, depending on the type of applied granulate, the dose and date of soil samples collection, was on average $7.28 \%, 7.94 \%$ and $30.5 \%$ higher than in the control.

Figure 1 shows the relationship between enzymatic activity of dehydrogenase, phosphatase and urease in soil after the use of sludge-ash granulates with varying share of sewage sludge and ash. 
Table 4. The impact of sludge-ash granulates on the activity of urease $\left(\mathrm{mg} \cdot \mathrm{N}-\mathrm{NH}_{4} \cdot \mathrm{kg}^{-1} \cdot \mathrm{ha}^{-1}\right)$ in the soil.

\begin{tabular}{|c|c|c|c|c|c|c|c|c|c|c|c|c|c|c|c|c|c|c|c|}
\hline \multirow{4}{*}{$\begin{array}{c}\text { Type } \\
\text { granulates* }\end{array}$} & \multicolumn{19}{|c|}{ Dose ${ }^{* *}$} \\
\hline & \multicolumn{5}{|c|}{1} & \multicolumn{5}{|c|}{2} & \multicolumn{5}{|c|}{3} & \multicolumn{4}{|c|}{ Mean } \\
\hline & \multicolumn{19}{|c|}{ Sampling times } \\
\hline & I & II & III & IV & \begin{tabular}{|l|} 
mean \\
\end{tabular} & I & II & III & IV & \begin{tabular}{|l|} 
mean \\
\end{tabular} & 1 & II & III & IV & mean & I & II & III & IV \\
\hline \multicolumn{20}{|c|}{ Ureaze in $\mathrm{mg} \cdot \mathrm{N}-\mathrm{NH}_{4} \cdot \mathrm{kg}^{-1} \cdot \mathrm{aa}^{-1}$} \\
\hline A & 7.73 & 7.69 & 7.78 & 7.85 & 7.76 & 7.88 & 7.95 & 8.09 & 8.21 & 8.03 & 8.25 & 8.35 & 8.41 & 8.50 & 8.38 & 7.95 & 7.99 & 8.15 & 8.18 \\
\hline$B$ & 7.77 & 7.81 & 7.87 & 7.91 & 7.84 & 8.03 & 8.11 & 8.15 & 8.21 & 8.12 & 8.38 & 8.40 & 8.51 & 8.62 & 8.48 & 8.06 & 8.10 & 8.21 & 8.24 \\
\hline C & 7.29 & 7.39 & 7.42 & 7.56 & 7.41 & 8.66 & 8.78 & 8.89 & 8.97 & 8.82 & 8.15 & 8.28 & 8.35 & 8.48 & 8.31 & 8.03 & 8.15 & 8.29 & 8.33 \\
\hline D & 7.31 & 7.36 & 7.48 & 7.59 & 7.43 & 8.71 & 8.89 & 8.97 & 9.12 & 8.92 & 8.21 & 8.34 & 8.41 & 8.56 & 8.38 & 8.07 & 8.19 & 8.37 & 8.42 \\
\hline Mean & 7.52 & 7.56 & 7.63 & 7.72 & 7.61 & 8.32 & 8.43 & 8.52 & 8.62 & 8.47 & 8.24 & 8.34 & 8.42 & 8.54 & 8.39 & 8.02 & 8.11 & 8.25 & 8.29 \\
\hline Control & \multicolumn{19}{|c|}{6.25} \\
\hline
\end{tabular}

* Explanations of the material composition of sludge-ash granulates are given as in Table 1.

** The size of granulated doses and the dates of soil samples collection are given "Material and method".

While analyzing the correlation coefficients $r=0.707$ at $p<0.05$, it was noted that the absolute phosphatase activity was positively correlated with urease activity. The correlation coefficient between dehydrogenase and urease and phosphatases activities was smaller but also positively correlated and amounted to $r=$ 0.569 and $r=0.553$, respectively. Similar results were obtained by Antonkiewicz et al. [2017], Krzywy-Gawrońska et al. [2009] and Wołoszyk et al. [2006]. The abovementioned relationships indicate the effect on soil enzymatic activity of applied sludge-ash granulates A, B, C and D. It is assumed that the stabilizing effect on urease, phosphatase and dehydrogenase is affected by both sewage sludge and ash from lignite, in which calcium and magnesium carbonates are present. The correlations between the activity of soil enzymes and the content of macroelements confirm the importance of intensity of nutrient removal from the soil environment [Pogrzeba et al. 2018, Wierzbowska et al. 2016]. Growing and fertilizing soil changes its physicochemical properties and increases its enzymatic activity. Kuziemska [2012] found that organic fertilization caused a significant increase in the activity of soil enzymes. Similar results were obtained as a result of granulate D application, which contributed to the greatest extent to the increase of phosphatase and urease.

To sum up, the highest increase in enzymatic activity of dehydrogenase was obtained after the application of granulate B produced with $40 \%$ sewage sludge, $20 \%$ ash, $10 \%$ sawdust and $15 \%$ ammonium phosphate and $\mathrm{KCl}$, and phosphatases and urease after using granulate D ( $50 \%$ sewage sludge, $20 \%$ ash, $10 \%$ sawdust, ammonium phosphate and $\mathrm{KCl}$ ). The smallest increases in dehydrogenase activity and phosphatases were obtained after the application of granulate $\mathrm{C}$ (20\% sewage sludge, $40 \%$ ash, $10 \%$ sawdust and $15 \%$ ammonium phosphate and $\mathrm{KCl}$ ). Waste in the form of sewage sludge, ash and sawdust used to produce granulates contributed to the increased activity of soil enzymes. The upward trend in enzyme activity under the influence of increasing doses of sewage sludge or composts with their participation is confirmed by many studies [Antonkiewicz et al. 2017, KrzywyGawrońska et al. 2009].

It was found that the granulates produced with the use of sewage sludge contain organic colloids and microorganisms that stimulate the activity of soil enzymes. Microorganisms support the use of soil macroelements by plants. Similar results were obtained by Pogrzeba et al. [2018]. Studies have shown that the dehydrogenase, phosphatase and urease activity, depending on the type of granulate applied and the size of dose, contributed - to a greater or lesser extent - to the increase in the enzymatic activity of soil. The research carried out by Antonkiewicz [2017], Bielińska et al. [2009], Wyszkowska et al. [2009] confirms the increase in the enzymatic activity of the soil as a result of the application of increasing doses of sludge and ash granules. The conducted experiment showed an increase in the activity of studied enzymes, which confirms the effectiveness of using the sewage sludge as a fertilizer in the cultivation of plants [Krzywy-Gawrońska 2012, Kołodziej et al. 2015, Kołodziej et al. 2016]. The research conducted by Synamowicz et al. [2018] confirms that mineral and organic fertilization increases the soil enzymatic activity, which was proven by the conducted research. 

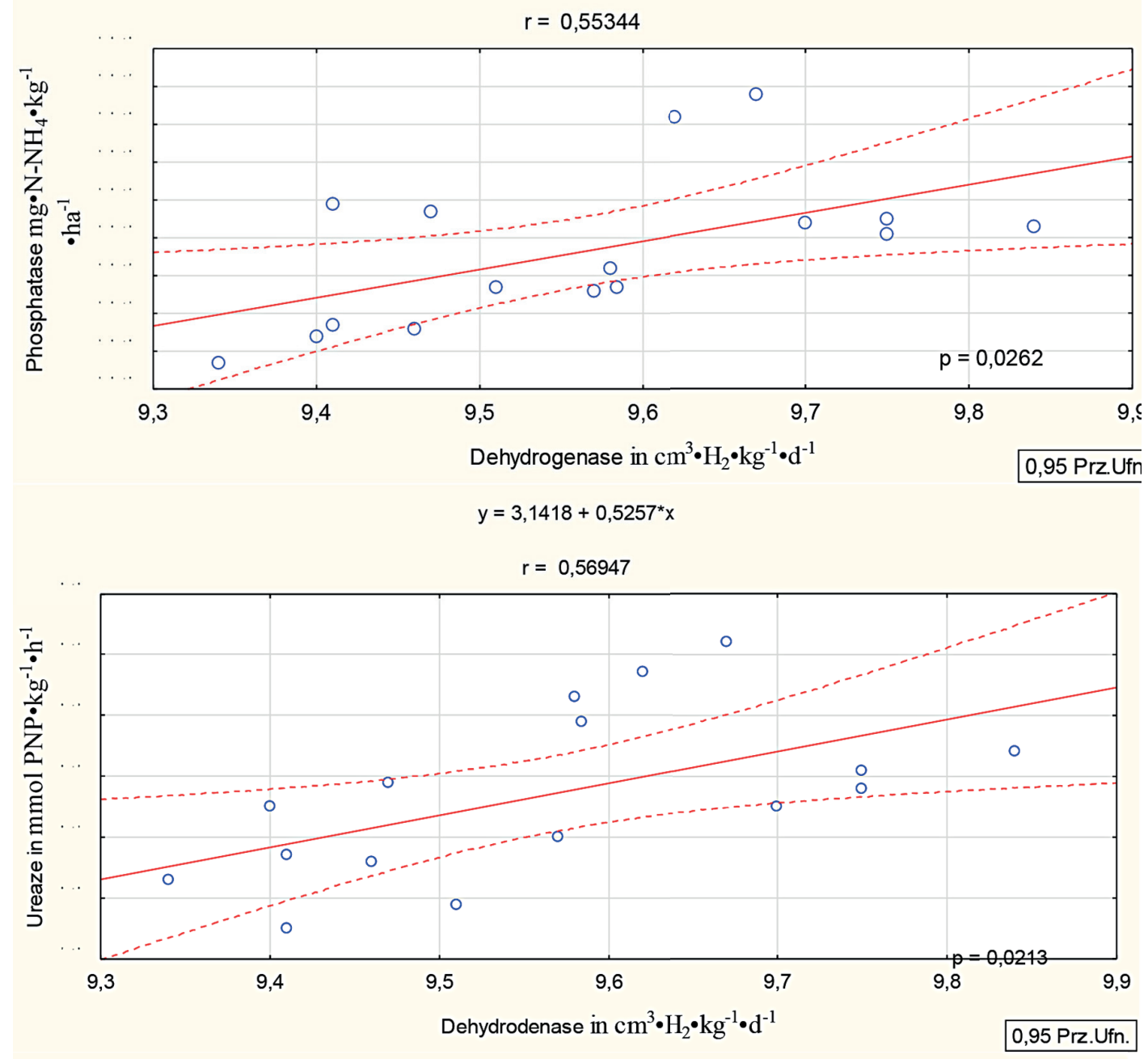

$y=0,2917+0,4844^{*} x$

$r=0,70772$

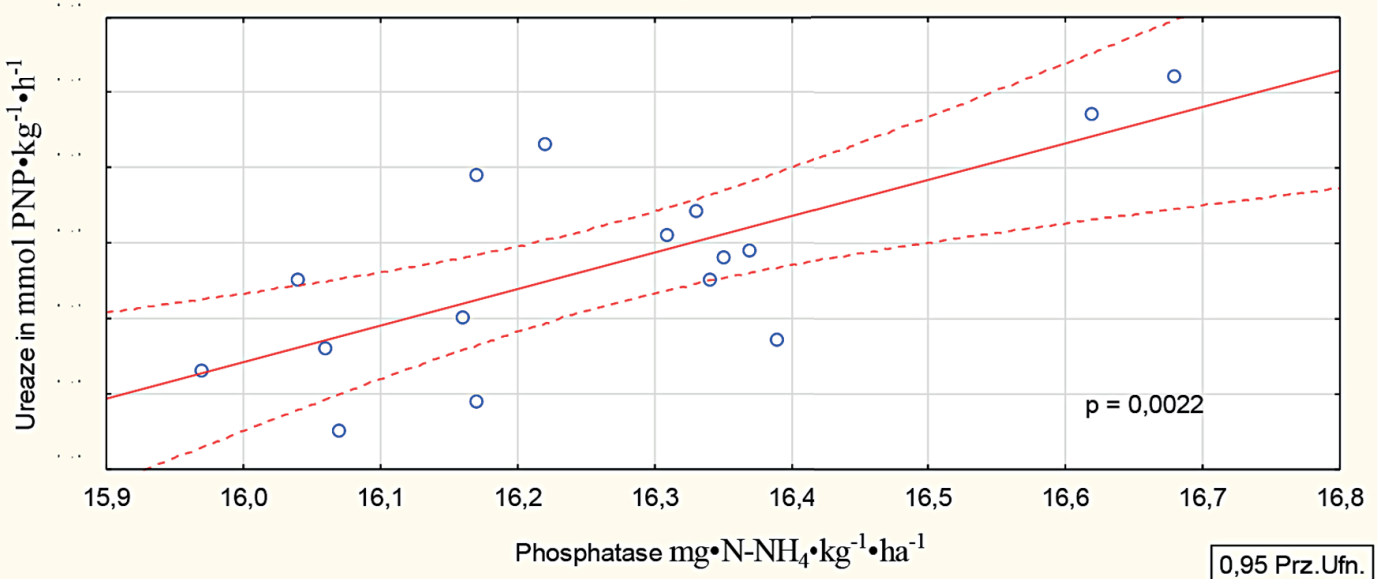

Figure 1. Relations between enzymatic activity of dehydrogenase, phosphatases and urease under the influence of applied sludge-ash granulates

\section{CONCLUSIONS}

Soil with applied sludge-ash granulates A, $\mathrm{B}, \mathrm{C}$ and $\mathrm{D}$ was characterized by higher activity of dehydrogenase, phosphatase and urease compared to the control. The highest increase in the enzymatic activity of dehydrogenase was obtained after the application of granulate B, and phosphatase and urease after the use of granulate D. The smallest increase in dehydrogenase and 
phosphatase activity was obtained after the application of granulate C. Studies have shown that the highest soil activity of dehydrogenase was obtained after the application of dose 1, 2 and 3 of granulate B, phosphatases - after application of dose 1 of granulate D, and urease - when applying dose 2 of granulate D. Fertilization with increasing doses of granulates contributed to the increase in dehydrogenase, phosphatase and urease activity from date I to IV of soil collection from beneath rapeseed by $7.41 \%, 7.68 \%$ and $30.5 \%$, respectively, compared to the control. Both the type of applied granulates A, B, C and D, increasing doses and the date of soil sampling had a significant impact on the increase in the activity of studied soil enzymes. The applied sludgeash granulates stimulated the enzymatic activity of dehydrogenase, urease and phosphatases on all fertilizer objects. Studies have shown that there is a significant correlation between the activity of dehydrogenase vs. phosphatases and urease in the soil, to which sludge-ash granulates were applied at various doses and times.

\section{Acknowledgements}

The study was partially carried out as part of the research project N 305358739 financed by the Ministry of Science and Higher Education.

\section{REFERENCES}

1. Antonkiewicz J. 2009. Assessment of the natural use of bottom ash and municipal sewage sludge. Zesz. Nauk. UR w Krakowie, 454(331), 5-25. (in Polish)

2. Antonkiewicz J. 2010. Effect of sewage sludge and furnace waste on the content of selected elements in the sward of leguje-grass mixture. $\mathrm{J}$ of Elemetology, 15(3), 435-443. DOI: 10.5601/ jelem.2010.15.3.435-443.

3. Antonkiewicz J., Kołodziej B., Bielińska E. 2017. Phytoextraction of hevy metals from municipal sewage sludge by Rosa multiflora and Sida hermaphrodita. Internacional Journal of Phytoremediation, 19(4), 309-318.

4. Antonkiewicz J., Kołodziej B., Bielińska E., GleńKarolczyk K. 2018. The use of macroelements from municipal sewage sludge by the multiflora rose and the Virginia fanpetals. Journal of Ecological Engineering 19(6), 1-13. DOI: 1012911/22998993/92889

5. Bielińska E.J., Baran S., Stankowski S. 2009. Assessment of suitability of fluidized ashes from hard coal for agricultural purposes. Inżynieria
Rolnicza, 6(11), 7-14.

6. Bielińska E.J., Futa B., Bik-Mołodzińska M., Szewczuk C., Sugier D. 2013. The impact of fertilizing agents on the enzymatic activity of soils. Journal of Research and Applications in Agricultural Engineering, 58(3), 15-19.

7. Kalembasa D., Kuziemska B., Kalembasa S., 2014. Effect of liming and organic materials on the activity of urease and dehydrogenases in nickel contaminated soil. Inżynieria Ekologiczna, 36(2), 7-17 DOI: $10.12912 / 2081139 X .01$

8. Kołodziej B., Antonkiewicz J., Stachyra M., Bielińska E.J., Wiśniewski J., Luchowska K., Kwiatkowski C. 2015. Use of sewage sludge in bioenergy production. A case study on the effect on sorghum biomass produtcion. European Journal of Agronomy 69, 63-74.

9. Kołodziej B., Stachyra M., Antonkiewicz J., Bielińska E.J., Wiśniewski J. 2016. The effect of harvest frequency on fielding and quality of energy raw material of reed canary Grass grown on municipal sewage sludge. Biomass and Bioenergy, 85, 363-370.

10. Kovàćik P., Macàk M., Ducsay L., Halcćinovà M., Janćich M. 2011. Effect of ash-fly ash mixture application on soil fertility. J of Elementology, 16(2), 215-225.

11. Krzywy E., Ciubak J., Cydzik E., Możdżer E., Kucharska M. 2012. The use of municipal sewage sludge and ash from lignite for the production of fertilizer granules. Chemik, 11(66),1163-1168.

12. Krzywy-Gawrońska E., Krzywy E., Wołoszyk C., Iżewska A., Krzywy I. 2009. Effect of PRP Fix substances on changes in enzymatic activity of dehydrogenase, phosphatase and urease in composts from municipal sewage sludge. Zesz. Prob. Post. Nauk Rol., 537, 207-215.

13. Krzywy-Gawrońska E. 2012. Enzymatic activity of urease and degydrogenase in soil fertilised with GWDA compost with or without a PRP SOL addition. Polish Journal Environmental Studies, 21, 949-955.

14. Kulikowski L., Piętka P., Kiepurski J. 2019. Processing sewage sludge for mineral-organic fertilizer on the mobile platform. Ecological Engineering, 20(1), 38-44.

15. Kuziemska B. 2012. The activity of dehydrogenases in the soil contaminated with nickel. Ochrona Środowiska i Zasobów Naturalnych, 52, 103-112.

16. Lemanowicz J., Koper J. 2012. Phosphatase activity and phosphorus content in soil from selected crops fertilized with slurry. Proceedings of ECOpole, 6(1), 239-243.

17. Łabętowicz J., Stępień W., Kobiałak M., 2019. Innovative technologies for processing waste into fertilizers for agro-ecological utility. Ecological Engineering, 20(1),13-23.

18. Możdżer E., Jałoszyński S. 2019. Effect of Fertilizer Granulates on Ionic and Weight Relations Among 
Macronutrients in Spring Rape Seeds. Journal of Ecological Engineering, 20(5), 52-58.

19. Możdżer E., Jałoszyński S., Jarnuszewski G. 2020. The impact of sludge-ash granulates produced with the use of industrial waste on the yield and quality characteristics of test plants. Fresenius Environmental Bulletin, 29(7), 4886-4895.

20. Piotrowska A., Koper J. 2007. Effect of long-term organic and mineral fertilization on the activity of redox and hydrolytic enzymes in soil under winter wheat (Triticum aestivum L.). Zesz. Probl. Post. Nauk Rol., 520, 669-673.

21. Pogrzeba M., Rusinowski S., Krzyżak J. 2018. Macroelements and hevy metals content in energy cros cultivated on contaminated soil under different fertilization-case studies on autumn harvest. Envronmental Science and Pollution Research, 25(12), 12096-12106. DOI: 10.1007/s11356-018-1490-8

22. Renella G., Chaudri A.M. Fallon C.M. Landi L., Nanniperi P., Brookes P.C. 2007. Effects Cd, Zn or both on soil microbial biomass and activity in a clay loam soil. Biol. Fert. Soils, 43, 751-759.

23. Synamowicz B., Kalembasa S., Nidbała M., Toczko M., Skwarek K. 2018. Fertilization of pea (pisum sativuml.) with nitrogen and potassium and its effect on soil enzymatic activity. J of Elementology, 23(1), 57-67. DOI: 10.5601/jelem.2017.22.1.1395

24. Tabatabai M.A. 1994. Soil ensymes. Methodes of soil analis. Part 2. Microbiologicea and biochemical properties, 55(5), 775-833.

25. Telesiński A., Chruściel M., Szymczak J. 2011.
Activity of o-diphenol oxidase in soil contaminated with cadmium, lead and copper. Aktywność oksydazy o-difenolowej w glebie zanieczyszczonej kadmem, ołowiem i miedzią. Ochr. Środ. Zas. Nat., 48, 216-222.

26. Thalman A. 1969. Zur metodik der Bestimmung der dehydrogenaseaktivitat in Bodenmittels Triphenylterazoliumchlorid. Landwirtsch. Forsch, 21, 249-258.

27. Trasar-Cepeda C., Leiros M.C., Gil-Sotres F. 2008. Hydrolytic enzyme activities In agricultura and forest soils. Some implications for thier use a indicators of soil quality. Soil Biol. Biochem, 40, 2016-2020.

28. Wierzbowska J., Sienkiewicz S., Krzebietke S., Sternik P. 2016. Sewage sludge as a skurce of nitrogen and phosphorus for Virginia fanpetals. Bulgarian Journal of Agriculture Science, 22(5), 722-727.

29. Wyszkowska J., Kucharski M., Kucharski J., Borowik A. 2009. Actity of dehydrogenases, catalase and urease in copper polluted soil. J of Elementology, 14(3), 605-617.

30. Wołoszyk C., Krzywy J., Joniak K., Krzywy E., Krzywy-Gawrońska E. 2006.Effect of composts and mineral fertilizers on the activity of dehydrogenase, acid and alkaline phosphatase and urease in soil before sowing and after harvesting spring rape. Zesz. Probl. Post. Nauk Rol, 512, 381-389.

31. Yang L., Li T., Li F., Lemcoff J.H., Cohen S. 2008. Fertizization regulates soil enzimatic activity and fertility dynamics in cucumber field. Sci. Hortic, 116, 21-30.

32. Zantua M., Bremner J.M. 1975. Comparsion of methods of assaying urease activity in soil. Soil Biol. Biochem, 7, 291-295. 